\title{
The Financial Debacle Necessitates a Systematic Approach to Achieving Ethical Behaviour in the Corporate Workplace
}

\author{
Clifton Clarke and Myles Bassell \\ City University of New York, United States
}

\begin{abstract}
The current vitriolic discourse over the financial scandals implicating Wall Street and its satellite institutions dictates a fresh look at strategies intended to eradicate or prevent unethical practices in business activities. The spate of recently published unethical behavior among business executives in the United States confirms, unequivocally, that past and current strategies have failed. This paper reviews and evaluates the impact of some of these strategies. It found that the strategies focus on legislation, written corporate codes of ethics and assorted activities in business schools. It found that these strategies are largely isolated and missed the fact that unethical business conduct is systemic, reflecting the ethical lapses of two systems: a public system (consisting of governmental bodies, business schools, and the general citizenry) and a corporate system (consisting of boards of directors, executives, managers and employees). It found that there is a significant gap between the rhetoric of corporate executives and their attention to unethical conduct in the workplace. It concludes that isolated legislative actions, apathetic business schools' policies, complacent and complicit corporate boards, contribute to the failure. It also concludes that, the implementation of business ethics in the workplace requires a transformation of attitude within and between these systems and posits that a system approach is the only strategy that can successfully transform these systems and that business schools are uniquely capable of leading this transformation.
\end{abstract}

\section{Keywords}

Ethics, financial crisis, corporate workplace, transformation, culture, business schools, casuistry, public policy, government regulation, unethical conduct

\section{Introduction}

Hearings held by a subcommittee of the Banking and Finance Committee of the United States Senate on certain practices of financial institutions, particularly those practices that might have contributed to the economic collapse in 2008 , revealed

Copyright (C) 2013 Victoria University. This document has been published as part of the Journal of Business Systems, Governance and Ethics in both online and print formats. Educational and non-profit institutions are granted a nonexclusive licence to utilise this document in whole or in part for personal or classroom use without fee, provided that correct attribution and citation are made and this copyright statement is reproduced. Any other usage is prohibited without the express permission of the publisher. the disconnect between the public's and corporations' perception of ethical conduct (Hauser 2010). Several of the questions posed to the Chief Executive Officer, and the Executive Director of Structure Products Group Trading of Goldman Sachs Group, Inc., focused on the company's ethics. For example, the senators wanted to know whether it was ethical for the company to sell investments that its own trading team knew were "worthless". In their defense, 
this and other questionable practices were an integral part of their company's business model. Similarly, Morganton (2011), of the New York Times reported that the former Chief Executive Officer of Countrywide Financial, then the largest mortgage lender in the United States, knowingly developed and sold questionable loans. He reported that "E-Mails and other documents supplied to regulators in the Security and Exchange Commission's ( S.E.C.'s) case against Mr. Mozilo showed him discussing the company's lending practices and describing some of its loans as 'toxic' and 'poison'. Nevertheless, the company kept selling the types of loans Mr. Mozilo was denigrating". For Mr. Mozilo the benefits of his action outweigh the cost, noting that "Countrywide was helping to breakdown the racial and economic barriers to homeownership. This approach went a long way to avoiding a serious social problem down the line" (Protests 2011). From the perspectives of these executives their actions were well within the boundaries of the free market system, a view rejected by the general public who saw the market ideology defense as a ruse to obfuscate their unethical, if not illegal practices. The public's position is consistent with that of Gras (1939), who argues that exploitation is an abuse of the capitalist system and is not inherent in the system itself. The contradictions alluded to are symptomatic of the discord between normative and practical ethics. It is not surprising that the conduct in question has resurrected the age-old debate over ethics, and in particular, business ethics and the role of business schools.

\section{Context and Definitions}

The advocacy for the integration of ethics into business and accounting education dates back many years. An editorial in the Journal of Accountancy posited that "Ethics should be a subject of study for every accounting student" (Journal of Accountancy 1953, p. 293). The American Accounting Association's Committee on Future Structure, Content and Scope of Accounting Education recommended inter alia that accounting education should provide students with the knowledge to "appreciate ethical standards and conduct" (The Bedford Committee 1986, p. 179). The National Commission on Fraudulent Financial Reporting calls for changes in accounting education to ". . . include ethics discussions in every accounting course" (The Treadway Commission 1987, p. 83). Derek C. Bok, former president of Harvard University urged the Harvard Business School to introduce ethics into their MBA curriculum (Bok 1983). In 1982, The Wall Street Journal reported on the proliferation of fraudulent and questionable financial reporting practices (Morris 1982). Recently, the highly publicized cases of fraudulent activities associated with the securities market and financial accounting reporting and practices (Bernard Madoff, Enron Corporation, The Galleon Group, Primary Global Research, Arthur Andersen, WorldCom) to name a few, has fueled a chorus of demand for ethical conduct from individuals in business. As the public looks for remedies to this seemingly corporate cancer the question as to the role of corporate boards in stemming these behavior in the workplace and the role of business schools in molding the character of their graduates grows louder and more pervasive. However, the precise actions expected from businesses and business schools have been evasive.

Philosophers and politicians have struggled with the concept of ethics for centuries with conflicting conclusions on how to define and implement it. Theodore Roosevelt (1858-1919), $26^{\text {th }}$ President of the United State is reported to have said "To educate a man in mind and not in morals is to educate a menace to society" (Roosevelt, n.d.) It is interesting to note that this was said in a period of U.S. history that is known for 'political discrimination', 'economic exploitation' and 'social segregation'. Despite their campaign for a just and moral society, Plato and Aristotle concurred that slavery was necessary for the success of their society (Taeusch 1931). Likewise the literature is saturated with debates and discussions on the need to improve ethics in business. Although there is a consensus that ethics should be at the core of business transactions, there are chasms among the myriad of interpretations and applications. The inconsistencies alluded to above reflect the challenge to wed general or normative ethics and situational or practical ethics. Critical questions such as what is ethics, are there two ethics (business and personal), what role the extant culture plays in decision-making, and what role can business schools effectively play in implementing ethics in the workplace, have not been sufficiently answered. 
A generally accepted definition of ethics is that it is the study of what is good and bad, right and wrong, just and unjust. Others such as Kohlberg described it as moral judgment and argued that "the exercise of moral judgment is a cognitive process" (Reimer et. al. 1983, p. 3). According to Cavanagh "ethics is a system of moral principles and the methods for applying them; ethics thus provides tools to make moral judgments. It encompasses the language, concepts, and models that enable an individual to effect moral decisions" (Cavanagh 1984, p. 137). De George (1987) defines ethics as the study of morality and immorality. Kaviya (2011) offers this explanation "ethics is the discipline dealing with that which is good and bad and with moral duty and obligation. Business ethics is concerned with the behavior of a businessman in doing a business and ... developed by the passage of time and custom. Custom differs from one business to another". Ethics, for some executives, has more nuances. It is casuistry, a cost-benefit calculation based on whether their behavior accrues benefits to their shareholders (Drucker 1983). This view point is consistent with the utilitarian theory of ethics (Bentham 1789) and (Mill 1863). Obviously, civil rights (Locke 1690) and justice (Aristotle 1953) are not factors in their decision set. These normative concepts are easily understood. The challenge is to implement them in tangible ways, that is, to construct strategies which promote business creativity and innovation, while simultaneously protecting all stakeholders.

The interpretation and therefore implementation of ethical principles are further complicated by social concerns. Since ethics involves the interaction among people, it functions in a social system, whether that system is the general society or the workplace or both. A social system undergirds culture, which may be defined as the values and ideology that influence decision-making. Values determine the basis on which choices are made. An ideology is comprised of the integrated values in a social system. It provides purpose, directions and identity to that system. Thus an ideology determines goals, strategies and reputation of a system. The implication is that ethics is communicated through social systems. The ideologies and strategies that government, corporations and business schools employ to combat unethical business conduct and their results are evaluated against this backdrop.

\section{Government and Ethics}

The solutions for unethical business conducts have evaded both federal and states governments for decades. The origin of governments' involvement in business ethics can be traced to the Sherman Anti-trust Act of 1890 (Taeusch 1931). The objective of that and subsequent laws is to prevent or to deter unethical conduct "through strengthening systems and controls, and promoting transparency, accountability and informed citizenry" (Chene 2010). The central features of major federal legislation discussed in this section illustrate the extent of governments' anti-fraud interventions. These legislative actions may be divided into two categories; those designed to protect consumers on the one hand and investors on the other. The Sherman Anti-trust Act of 1890, and the Clayton Act of 1914, are among the first set of consumer protection legislations (Taeusch 1931). The former aims to prevent restraint of interstate and foreign trade while the later prohibits price discrimination in contracts and other agreements that restrict competition. The Foreign Corrupt Practices Act (FCPA) of 1977 and revised in 1988 has anti-bribery prohibitions and accounting and record-keeping requirements (Gaetti 1997). The anti-bribery prohibitions "make it illegal for U.S. persons to bribe a foreign government official for the purpose of obtaining or retaining business" (Gaetti 1997). The record-keeping provisions require publicly traded companies in the U.S. "to devise and maintain an accounting system which tightly controls and accurately records all dispositions of company assets" (Gaetti 1997). The Credit Card Accountability Responsibility and Disclosure Act of 2009 (the Credit Card Act) prohibits predatory practices in the credit card industry and confirms certain consumer rights (Detweiler 2009). The Dodd-Frank Wall Street Reform and Consumer Protection Act of 2010 were enacted to protect both consumers and investors. It, among other things, regulates transactions in products such as home mortgages, car loans, credit cards and certain derivatives. The oversight of these legislations is distributed among a maze of governmental agencies which oftentimes have overlapping objectives and contrary enforcement practices.

The securities markets are subject to the oversight of the Securities and Exchange Commission (SEC). The purpose of the SEC is to protect investors and maintain market integrity. The online publication 
"How the SEC Protects Investors, Maintains Market Integrity" discusses the main legislations in pursuit of this objective. The Securities Act of 1933 requires publicly traded companies to register their securities and accurately disclose financial and other information that will influence investors' decisions. It also prohibits deceit, misrepresentations, and other fraud in the sale of securities. The Securities Exchange Act of 1934 regulates companies and individuals engaged in the sale and exchange of securities. It also authorizes the SEC to require periodic reporting of information by companies with publicly traded securities. The Investment Company Act of 1940 regulates the organization of companies engaged primarily in investing and trading in securities offered to the investing public. The Investment Advisers Act of 1940 and amended 1996, with certain exceptions, requires investment advisers to register with the SEC and comply with rules designed to protect investors. Finally, the Sarbanes-Oxley Act of 2002, was enacted in response to the Enron, WorldCom and other similarly high profile scandals. It, among other things, mandated several reforms to guard against corporate and accounting fraud. Since 1991 the enforcement strategies have been augmented by the federal sentencing guidelines designed to encourage ethical conduct in the workplace (Desio 2004). Despite these strategies by government, unethical business behavior continues in various forms. The strategies employed by corporations have produced no better results.

\section{Corporate Culture and Ethics}

The origin of unethical business practices is unknown. However there are events in history which indicate that it is not a recent phenomenon. These events demonstrate that unethical behavior is not a victimless activity. Unfortunately, it usually takes egregious incidents to expose the injury it inflicts on individuals and society. One of the earliest reported incidents is in the Holy Bible (Mathew 21: 12), where it is reported that Jesus in a rage directed mainly at the moneychangers (bankers), drove the merchants and moneychangers out of the temple (Scripture Backdrops). The moneychangers were notorious for charging pilgrims exorbitant foreign exchange rates and fees (Scripture Backdrops). Taeusch (1931) opined that business ethics emerged at the peak of the westward migration. He asserts that "from this time on, excess social, political, and economic energies could no longer expend themselves on a virgin territory, but reacted more and more upon established human communities. It is in such reflective situations that ethical considerations arise; and so they arose in our economic life, first in the form of labor disturbances and agrarian readjustments, and later in the sharper conflicts of business competition" (Taeusch 1931, p. 53). De George (1987) and Gras (1939) suggested that attention to ethics in business has its origins in religious values; the expectation that one should be concerned about the wellbeing of others.

While there may be a universal expectation of corporations to do what is good, right and just, the question remains as to what is good or bad, right or wrong, just or unjust in business. Drucker and others have expressed skepticism of the very idea of a business ethics. He asked, ". . . if there is indeed something that one could call business ethics and could take seriously, what could it be?" (Drucker 1993, p.195). There are two main theories of business ethics. One is the theory of moral unity which holds that business actions can be judged by the general ethical standards of society (Steiner and Steiner, 1985). This point of view is consistent with those of moralists such as F. H. Bradley (Ethical Studies, 1876), Edmond Cahn (The Moral Decision, 1955) and Aristotle (Ethics, 1953). However, moralists do allow for unethical behavior in "extenuating" and "aggravating" circumstances based on social and cultural mores. For example, they accept that a poor widow who stole bread to feed her starving children should receive clemency. In Nicomachean Ethics, Aristotle suggests that unethical behavior caused by ignorance and incapacity to perform an action should be excused. As Gras (1939) observed, "Unhappy lies the head of the moralist, for he must try to fit parts that do not match" (Gras, 1939, p. 315).

Another school of thought, the amoral theory argues that business activity is amoral and so decisions should be based solely on considerations of economic self-interest (Steiner \& Steiner 1985). This economic theory and its contaminant business practices flourished in the nascent period of capitalism under the doctrine of Social Darwinism (survival of the fittest) and laissez-faire economics. This doctrine underpins the philosophy of Adam Smith (1904) and others who believe that the common 
good is best achieved by individual pursuit of their self-interest. This line of thinking is the central tenet of corporate practices. The financial crisis of the U.S. in the 1930's and the subsequent intervention of the federal government in the economy (the New Deal) at least modified the scope of business autonomy and thereby the behavior of individuals in business. The resurrection of the doctrine of 'survival of the fittest' saw a resurgence of business practices that are obviously not good, not right and not just. Some of the purveyors of these practices have been prosecuted. Others such as those associated with certain practices related to subprime mortgages and credit swaps and the subsequent collapse of the housing market are being investigated. Both the moral and amoral theories have some validity. Groups of all kinds need a set of principles that guide the behavior of their members. However, individuals must have the space to create, innovate, and to benefit from the fruits of their action.

Ultimately, ethics is practiced by individuals, and so it cannot be evaluated in a vacuum. The challenge individuals face is how to apply general principles of ethics in the context of the situation that confront them. A survey conducted by Merchant (1987) suggests three reasons for the spate of fraudulent and questionable financial reporting experienced then and which seem appropriate now. The first reason is that incentives and other inducements, such as the 3P's Pay, Promotion and Praise, have become ends. Managerial performance is measured in terms of results. Results are what justify means. "The means-ends ethics" is often associated with the Italian political philosopher Niccolo Machiavelli. In the Prince he wrote that worthwhile ends justify efficient means, that when ends are of overriding importance or virtue, unscrupulous means may be employed to reach them. The second reason is temptations, the ineffectiveness or nonexistence of corporate controls to detect managers' deceptive practices. The third reason is the lack of moral guidance and leadership from top management.

Merchant (1987) concluded that corporations could resolve these problems by using strong penalties for violations, by using realistic performance targets, and by deemphasizing short-term goals. The implementation of these suggestions may serve as deterrents for some employees, but they missed the salient point and that is, unethical behavior is system induced and nurtured. A system will produce the best product it is designed to produce, the saying goes. Corporate systems are designed to produce profits, first and foremost. If ethical behavior generates profits, businesses will provide incentives and rewards to employees who adhere to ethical standards.

A study of businesspeople by Baumhart shows that most believe a code of ethics would help them clarify their own standards and decisions (Baumhart, 1961). In essence, business executives are not against the concept of ethics and a large majority have developed written codes of conduct for their own firms. The struggle between normative and practical interpretation of ethics is a challenge for business executives in a viciously competitive world. They need successful models, that is, proven practices and processes that produce measurable outcomes. Ethics, as a discipline, lacks these attributes and therefore it does not offer the confidence executives need to plan. Planning is about the future. The future is a dark place and no executive will enter there without some protection. It was probably in recognition of this vagueness that Blumenthal, former chair of Burroughs Corporation and Bendix, and secretary of the United States Treasury, proposed the establishment of a national code of business ethics among Chief Executive Officers (Blumenthal 1975). It was in the same vein that The Caterpillar Tractor Company developed and distributed its own code of conduct to its managers worldwide (Caterpillar 1974). These proposals were widely accepted as evidenced by the growth in the number of firms that subsequently created ethics committees within their boards of directors (Cavanagh 1984).

The number of firms with written codes of conduct has grown since the 1970's. Kerin, et al (2007), estimated that " 80 percent of United States companies have some sort of ethics code and one of every five large companies has corporate ethics officers "(Kerin et al. 2007, p. 84). However, the actions of some companies could have been driven by the plethora of damaging disclosures regarding unethical and illegal acts in which of some of the largest American firms engaged during the 1970's (Ross 1980). Such conduct was not confined to activities in the United States. According to Clinard \& Yeager (1980), many corporations were implicated in the practice of paying bribes to 
officials. The growth in corporate ethics programs might also be motivated by the 1991 Federal Sentencing Guidelines for Organizations (Joseph 2003). It provides for a significant financial incentive to corporations who implement these guidelines. Programs that follow the sentencing guidelines may receive a reduction of up to 95 percent in Federal Government fines (Desio 2004). Regardless of the reasons companies develop codes of conduct; the evidence shows that their strategies are not succeeding. As recent as April 2010 the U.S. Justice Department and the Security and Exchange Commission were investigating whether Hewlett Packard Company executives paid millions of dollars (US) in bribery money between 2004 and 2006 to the Prosecutor General of Russia to win a large contract to supply computer equipment throughout Russia (Crawford 2010). More recently, Tyson Foods settled bribery charges with the Justice Department (Neuman 2011). Surprisingly, or maybe not, there is no evidence that the executives of the accused accompanies have ever conceded that their conduct was unethical.

Although these practices are reprehensible, they do not confirm that business executives are necessarily unethical. Their priority is to maximize the wealth of their shareholders in a highly competitive environment. This requires them to make assumptions about the future based on tested and proven models. Ethics is an amorphous concept and is often discussed in normative rather than practical terms. For a short time ethics was synonymous with social responsibility a concept embraced by business executives. However, it can also be morphed into self-justification. Wright, quoting a former corporate executive wrote "the system of American business often produces wrong, immoral and irresponsible decisions, even though the personal morality of the people running the business is often above reproach" (Wright 1979, p. 61). This comment can be summed up with this piece of cynicism: "An ambassador is an honest man, lying abroad for the good of his country" (Wotton, n.d.). The case of the CEO of Galleon Group exemplifies this conundrum. The prosecution accused him of knowing "tomorrows business news and traded on it" but his lawyer countered that he obtained information through "shoe-leather research, diligence and hard work" (Lattman 2011). Bridgeport Education, an online education company, is another example of normative versus practical ethics. The company obtains 86 percent of its revenue from the federal government. Its dropout rate ranges from 63 to 84 percent depending on the degree program and they paid little attention to job placement, a crucial promise to students. Their per student costs were allocated as follows: $\$ 700$ went to instruction, $\$ 2,700$ went to recruiting and $\$ 1,500$ went to profit. Their justification for this perceived abuse of students was that they provide education at a lower cost to taxpayers than public colleges (Lewin 2011).

Despite the heightened awareness, there is no noticeable impact on corporate unethical practices. A possible reason is an absence of leadership on this issue among business executives. Leadership is reflected in the perceived message from top management and not necessarily in a written code of conduct. The ethical tone set by top executives should be the doctrine of the workplace, that is, every employee should be indoctrinated in those values. The positive effects of indoctrination will outweigh any negative concerns. A review of surveys conducted by the Ethics Resource Center (ERC) revealed a persistently significant gap between executives' rhetoric and their actions. The 2007 National Business Ethics Survey (NBES) survey shows that only one in four companies has a well implemented ethics compliance program. Although The 2009 NBES survey found that an ethical culture in the workplace is highly regarded and that there is awareness among executives that financial fraud or other misconduct can be discovered before the damage shows up in financial reporting if there is an ethical culture in the workplace, unethical conduct persists in corporations. In the executive summary of the 2000 NBES survey, the Ethics Resource Center reports that "one in eight employees feel pressure to compromise their organizations' ethics standard." According to the 2005 NBES survey, ethical misconduct returned to the pre-Enron levels during 2005, and, as was in 2000 survey, one in eight employees experience some form retaliation for reporting misconduct. More recently, the 2009 NBES survey reported an increase in retaliation against those who reported misconduct in the workplace. Studies conducted by Bolt-Lee, Farber \& Moehrle (2011), of among other things, whistleblowing in corporations found similar pattern of retribution against auditors and employees. They found that the auditors who reported findings of fraud were not rewarded. However 
there was an "approximately 50\% probability that the whistleblowing auditor would lose the account of the company involved in the irregularity", and " $82 \%$ of named whistleblowers alleged they were either fired, forced to quit or demoted after blowing the whistle" (Bolt-Lee, Farber \& Moehrle 2011, p. 38). The 2009 NBES Supplemental Research Briefs found that "Actions - and Perceptions - of top managers drive the ethical culture of the company and have a significant impact on outcomes" (NBES 2009 , p. 8). Such impact includes the prevention of the kinds of workplace behavior that can put a business at risk. The 2009 NBES survey also found that "in a weaker ethical culture, employees observe more misconduct" (NBES 2009, p. 16). These findings raise questions about the commitment of corporate executives to implementing ethics in the workplace. Any positive response from corporate executives may be driven primarily by mitigating factors against punishment rather than concerns about social responsibility. Clearly, corporate culture or what Sonenshein characterized as thick or organization moralities (Sonenshein 2005), is the primary determinant of the degree of ethical behavior in the workplace.

Corporations are living organisms. They have culture, leadership and emotion. They experience desperation, depression, denial, hope, and fear (Foster \& Kaplan 2001). Most of all they have mental models. These are "the core concepts of the corporation, the beliefs and assumptions, the cause-andeffect relationships, the guidelines for interpreting language and signals, the stories repeated within the corporate walls" (Foster \& Kaplan 2001, p. 18). Corporate systems are built on mental models, some of which have produced less than virtuous results. Mental models are invisible, implicit, yet real, enduring and omnipresent. It develops and nurtures interrelationships and interdependence. The workplace is an ecosystem and as with other ecosystems adaptation is imperative for the survival of its members and the system itself. System thinking is pervasive, that is, the view that an organization is effected by what happens to the parts. It encourages cohesiveness, positively or negatively, among employees. Senge defines system thinking as "the discipline that integrates the disciplines (personal mastery, mental models, building shared vision, team learning), fusing them into a coherent body of theory and practice" (Senge 1990, p. 12). A corporation is also a learning organization "a place where people are continually discovering how they create reality and how to change it" (Senge 1990, p. 13). People in the workplace slide between two realities, namely, personal culture and the culture of the workplace. The decisions they make may be based on moral or amoral principles. It depends on the corporate culture and by extension, corporate boards.

Corporate boards of directors have a crucial role in the quest to eradicate unethical business practices. The boards of directors are the official management of corporations. It is at this level that the ideology and message regarding ethical standards should emanate as do all other policies and strategies of the corporation. According to Gras (1939), "Business ethics is the reservoir of clear water which may be drawn upon to build the codes of industry. It is a lake upon which the individual firm can sail its ship into the harbor of Good Policy" (Gras 1939, p.310). Although investors sometimes chided directors for the under-performance of their corporation, they usually escape punishment for the unethical behavior of their executives. This breeds complacency and contempt for ethical issues. The SEC's suit against the directors of DHB Industries might represent a change in this practice. The SEC accused three ex-board members of DHB Industries of "willful blindness", alleging that they turned a blind eye while the company sold defective armor to the military and law enforcement agencies (Norris 2011). This action was welcome by investors and members of the legal and enforcement communities, but a more proactive approach might have avoided the victim's suffering in this alleged fraud. The SEC's charges signals that board members must become proactive on matters of ethics because they may be held accountable for the malfeasances of their executives. Business schools have the ability and capacity to assist corporate executives with their ethical challenges.

\section{Business Schools and Ethics}

The role of business schools in the moral development of their graduates is not settled. It is reasonable to assume that most, if not all students, have some notion of what is good and bad, right and wrong, just and unjust in the abstract. The purpose of business schools is to provide their graduates with among other skills, critical thinking. Teaching is a process which results in the voluntary modification 
of the behavior or thought of others. In so doing it should produce critical thinkers. "Good teachers produce skeptics who ask their own questions and find their own answers" (Ackoff \& Addison 2007, p. xi). Ethics is a diffused discipline and by extension business ethics is an undefined body of knowledge. Therefore, the application of ethics is invariably the product of critical thinking, which is influenced by the environment in which the decision is being made. Subjectivity often trumps objectivity in crucial circumstances, therefore a set of rules must be available for reference at all times. The workplace is highly competitive and corporate culture, directly or indirectly, provides the weapons used in this combative environment. It is where the feedback loop of performance and reward is established, evaluated and controlled. Against this backdrop, business schools should not be expected to teach their graduates to unilaterally disarm. This could lead to career suicide. As Machiavelli observed, "it is not reasonable to suppose . . . that any unarmed man will remain safe among armed servants" (Buskirk 1974, p. 40). Business schools can and should create awareness. However, such knowledge is impotent or at best a blunt instrument in an unethical culture.

Business schools provide ethics education through various means. In addition to course materials they have encouraged ethical behavior among their graduates through honor societies and other means. Professor Nitin Nohria (who became Dean of Harvard Business School in May 2010), has been actively promoting business ethics for more than two decades. He has been leading the crusade to adopt an MBA Oath. The Oath is a voluntary pledge for graduating and current MBAs to "create value responsibly and ethically." MBA students, graduates and advisors representing over 250 business schools worldwide, the Aspen Institute and the Economic Forum are participating in this Oath (The MBA Oath). There is nothing new about professional and organizational Oaths. The Hippocratic Oath, Thunderbird's Oath of Honor and the Columbia Business School's Honor Code are notable examples. These activities are necessary but are obviously insufficient to prevent unethical behavior by their graduates. Therefore, business schools must become more innovative if they are to remain credible in the quest for solutions to this scourge.

\section{Conclusion}

The need for a more ethical workplace is no longer debated. It is also a demonstrable fact that there is a colossal failure of the current strategies employed to control unethical conduct in the workplace. Laws have been enacted, codes have been written, oaths have been taken and pledges have been made but they all fell short of their objectives. The federal government has tacitly admitted the failure of the legislative approach by its resorting to a cooperative posture through the sentencing guidelines developed by the United States Sentencing Commission. One is not sure of the extent to which business schools can influence the ethical behavior of their graduates but they can help corporations. One of the main reasons the strategies fail is that there is a lack of meaningful collaboration amongst business schools, corporate boards, and government. The justification for their collaboration is selfevident. Firstly, there is a natural link between the three institutions, the responsibility to protect the public interest. Secondly, there is a need to bridge the divide between normative ethics as taught by business schools and the ethical challenges that confront corporations. This presents a unique opportunity for business schools to take a leading role in ameliorating this intractable problem. Business schools can begin to demonstrate their commitment to developing ethical corporate workplaces by establishing direct contact with corporate boards and by hiring faculty who are business ethicists and avail their services to corporations. These are faculty who appreciate the concerns of business executives, understand how corporations work, and are dedicated to protecting the interest of the public.

Corporate boards of directors can reciprocate by appointing a member whose sole responsibility is to develop, monitor and enforce ethical standards in the workplace. This member would be required as a matter of corporate policy to establish consultative relationships with ethics faculty at business schools. Parenthetically, the new posture of the SEC might encourage this direction. The relationship will facilitate the flow of ideas and best practices amongst business schools, corporations, and government. It will also intersect the application of normative and practical ethics. It is essential because ethical questions usually arise at the margin. For example, a discussion may occur on issues 
of disclosure; what should be disclosed, to whom it should be disclosed, and when it should be disclosed. Taken separately or in any combination, the response to these questions can have significant financial and public relations consequences. The notion of corporations obtaining external opinions is not new. They routinely seek the advice of external professionals such as lawyers. While corporate executives may be impaired by parochial ideologies, independent business ethicists would not be restrained by such handicaps, thus allowing for better decisions.

Clearly, the engagement and cooperation of business schools, corporate boards, and government at a level that matters can transform attitudes, policies and practices within the public and private systems. The nature of the problem requires coordinated solutions. A systematic approach is the only strategy that can provide these solutions.

\section{References}

Ackoff, R.L., \& Addison, H. L., (2007), Management f-Laws: How Organizations Really Work. Triachy Press, United Kingdom,.

Aristotle, trans. J.A.K. Thomson (1953), Ethics, Penguin, , London.

Baumhart, R. C. (1961), 'How Ethical Are Businessmen?' Harvard Business Review, vol. 39, JulyAugust, 1961, pp. 66 - 71.

Bentham, J. (1789/1948), An Introduction to the Principles of Morals and Legislation. Hafner, New York.

Blumenthal, W.M. (1975), 'New Business Watchdog Needed', The New York Times, 25 May, 1975, sec. F., p. 1.

Bok, D. (1983), 'Students Need to Grapple with Significant Ethical Problems', U.S. News \& World Report, 21 February, 1983, p. 83.

Bolt-Lee, C. E., Farber, D. B. \& Moehrle, S. R.. (2011), 'Highlights of Corporate Governance Research' Journal of Accountancy, September 2011, pp. 34-39.

Buskirk, R. H. (1974), Modern Management \& Machiavelli. New American Library, New York.

Caterpillar Tractor Company (1974), 'A Code of Worldwide Business Ethics', viewed 10 February 2011, http://www.caterpillar.com/company strategy/code-of-conduct.

Cavanagh, G. F. (1984), American Business Value, 2 ed., Prentice-Hall, New Jersey.

Chene, M. (2010), 'International Good Practice in Anti-corruption Legislation: General Principles', Anti-corruption Resource Center, No. 233, viewed 20 January, 2012, www.U4.no.

Crawford, D. \& Searcey, D. (2010), 'U.S. Joins H-P Bribery Investigation', The Wall Street Journal, viewed 17 April, 2011.

http://online.wsj.com/article/SB1000142405270304628704575186151115576646.html?mod=WS J.

Clinard, M. B. \& Yeager, P.C. (1980), Corporate Crime, Free Press, New York.

De George, R. T. (1987), 'The Status of Business Ethics: Past and Future', Journal of Business Ethics, Vol. 6, pp. 201-211.

Desio, P. (2004), 'An Overview of the Organizational Guidelines, Washington, DC: United States Sentencing Commission', viewed 2 March, 2011, 
http://www.globalcompliance.com/LinkClick.aspx?fileticket...tabid=170. Also see http://www.ussc.gov/TRAINING/corpover.PDF.

Detweiler, G. (2009), 'Understanding The Credit Card Accountability Responsibility and Disclosure Act of 2009: Public Law 111-24', viewed 20 January, 2012, http://www.credit.com

Dodd-Frank Act (2010), 'Brief Summary of Dodd-Frank Wall Street Reform', viewed 12 June, 2011, http://banking.senate.gov/.../070110_Dodd_Frank_Wall_Street_Reform...

Drucker, P. F. (1983), The Ecological Vision: Reflections on the American Condition, Transaction Publishers, New Jersey.

Eder, S. \& Margolis, D. (2010), 'Goldman CEO faces blistering attack over ethics', The New York Times, 28 April, 2010, p. B1.

Foster, R., and Kaplan, S. (2001), Creative Destruction: Why Companies That Are Built to Last Underperform the Market and How to Successfully Transform Them, Doubleday, New York.

Gaetti, M.M, Organdy, C. R. G., and Morgan, O. F. (1997), "Foreign Corrupt Practices Act", Gaetti \& Associations, viewed 20 January, 2012, http://library.findlaw.com/1997/Jan/1/126234.html.

Gras, N. S. B. (1939), Business and Capitalism: An Introduction to Business History, F. S. Crofts \& Co., New York.

Hauser, C. (2010), “In Washington, Battles in Two Rings”, The New York Times, 28 April, 2010, p. B1.

'How the SEC Protects Investors, Maintains Market Integrity', viewed 11 April, 2011, http://www.sec.gov/about/laws.shtml.

Hudson, R.L (1983), 'SEC Charges Fudging of Corporate Figures Is a Growing Practice', The Wall Street Journal, 2 June, 1983.

Joseph, J. (2003), 'National Business Ethics Survey: How Employees View Ethics in their Organizations', Washington DC, Ethics Resource Center.

Kaviya, S. (2009), "Ethics in Management”, viewed 20 January, 2012, http://www.articlesbase.com/ethics-articles/ethics-in-management-1535462.html

Kerin, R. A., Hartley, S. W., \& Rudelius, W. (2007), Marketing: The Core, 2nd edn., McGraw-Hill Irvin, New York.

Lattman, P. (2011), 'In Galleon Trial, Arguing Greed vs. a Picture of Diligent Research', The New York Times, 10 March, 2011, p. B1.

Lewin, T. (2011), 'Hearing Sees Financial Success and Education Failures of For-Profit College', The New York Times, 11 March, 2011, p. A17.

Locke, J. (1690/1952), The Second Treatise of Government, Liberal Arts Press, New York.

Merchant, K. (1987), 'Fraudulent and Questionable Financial Reporting: A Corporate Perspective', Financial Executive Foundation, Morristown New Jersey.

Mill, J. S. (1863/1957), Utilitarianism, Bobbs-Merrill, Indiana.

Morris, B. (1982), 'Accounting Scams are on the Rise, Putting More Pressure on Auditors', The Wall Street Journal, 9 July, 1982, p. 19. 
Morganton, G. (2011), 'Case on Mortgage Official Is Said to Be Dropped', The New York Times, 20 February 2011, p. 20.

National Business Ethics Survey (2000), "Executive Summary: Major Findings", Ethics Resource Center. viewed 20 January, 2012, http://www.ethics.org/resource/2000-national-business-ethics-survey-nbes

National Business Ethics Survey (2005), Ethics Resource Center. viewed 20 January, 2012, http://www.ethics.org/resource/2005-national-business-ethics-survey.

National Business Ethics Survey (2007). Ethics Resource Center. viewed 20 January, 2012, http://www.ethics.org/resource/2005-national-business-ethics-survey-nbes

Neuman, W. (2011), 'Tyson Settles U.S. Charges of Bribery', The New York Times, 11 February, 2011, p. B1

Norris, F. (2011), 'For Boards, S.E.C. Keeps The Bar Low', The New York Times, 4 March, 2011, p. B1.

Protests, B. (2011), 'From Ex-Chief, a Staunch Defense of Countrywide's Legacy', The New York Times, 18 February, 2011,p. B5.

Reimer, J., Paolitto, D.P., \& Hersh, R.H. (1983), Promoting Moral Growth from Piaget to Kohlberg, Longmans, New York.

Ross, I. (1980), ‘How Lawless Are Big Companies?’ Fortune, 1 December, 2011, pp. 56-64.

Sarbanes-Oxley Act (2002), 'Sarbanes Oxley Act of 2002 Summary and Introduction', viewed 20 January, 2012, www.Soxlaw.com/introduction.htm

Scripture Backdrops, 'Relevant Historical Insights Into Scripture', viewed 20 January, 2012, http://www.bible-history.com/backd2/moneychangers.html

Senge, P. F. (1990), The Fifth Discipline: The Art \& Practice of The Learning Organization, New York, Doubleday.

Smith, Adam. An Inquiry into the Nature and Causes of the Wealth of Nations. Edwin Cannan, ed. 1904. Library of Economics and Liberty, viewed 20 January, 2012, http://www.econlib.org/library/Smith/smWN.html

Sonenshein, S. (2005), Business Ethics and Internal social criticism, Business Ethics Quarterly, Vol. 15, No.3: pp. 475-498.

Steiner, G.A., Steiner, J.F. (1985), Business, Government, and Society, 4th edn., Random House, New York.

Supplemental Research Briefs, NBES (2009), The importance of Ethical Culture: Increasing Trust and Driving Down Risks, Ethics Research Center, Virginia.

Taeusch, C. F. (1931), Policy and Ethics in Business, McGraw-Hill Book Company, Inc., New York.

The Bedford Committee (1986, Spring), 'Future Accounting Education: Preparing for the Expanding Profession', Committee on the Future Structure, Content, and Scope of Accounting Education, American Accounting Association, pp. 168-195. 
The MBA Oath: Responsible Value Creation, viewed 20 January, 2012, http://mbaoth.org.

The Treadway Commission (1987), 'Report on the National Commission on Fraudulent Financial Reporting', October.

Roosevelt, T. (n.d.), viewed 20 January, 2012,

http://www.brainyquote.com/quotes/quotes/t/theodorero147876.html

Wotton, H. (n.d.), viewed 20 January, 2012,

http://www.searchquotes.com.quotes/author/Henry_Wotton_Sr

Wright, J. P. (1979), On a Clear Day You Can See General Motors, New York, Avon Books.

Reprinted in G.A. Steiner and J.F. Steiner (1985). Business, Government, and Society, 4th edn., Random House, New York. 